\title{
Effects of different ratios and storage periods of liquid brewer's yeast mixed with cassava pulp on chemical composition, fermentation quality and in vitro ruminal fermentation
}

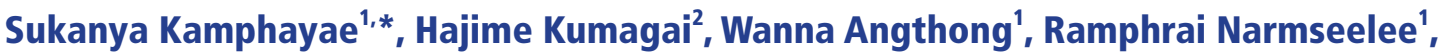 \\ and Smerjai Bureenok ${ }^{3}$
}

\footnotetext{
* Corresponding Author: Sukanya Kamphayae Tel: +66-95-649-0770, Fax: +66-4326-1087, E-mail: sukanyaa@dld.go.th

'Khon Kaen Animal Nutrition Research and Development Center, Khon Kaen 40260, Thailand 2 Laboratory of Animal Husbandry Resources, Division of Applied Biosciences, Graduate School of Agriculture, Kyoto University, Sakyo, Kyoto 606-8502, Japan

${ }^{3}$ Faculty of Sciences and Liberal Arts, Rajamangala University of Technology Isan, Nakhon Ratchasima 30000 , Thailand
}

Submitted Mar 16, 2016; Revised May 24, 2016: Accepted Jun 11, 2016
Objective: This study aims to evaluate the chemical composition, fermentation quality and in vitro ruminal fermentation of various ratios and storage periods of liquid brewer's yeast (LBY) mixed with cassava pulp (CVP).

Methods: Four mixtures of fresh LBY and CVP were made (LBY0, LBY10, LBY20, and LBY30 for LBY:CVP at 0:100, 10:90, 20:80, and 30:70, respectively) on a fresh matter basis, in $500 \mathrm{~g}$ in plastic bags and stored at 30 to $32^{\circ} \mathrm{C}$. After storage, the bags were opened weekly from weeks 0 to 4 . Fermentation quality and in vitro gas production (IVGP) were determined, as well as the dry matter $(\mathrm{DM})$, organic matter $(\mathrm{OM})$, crude protein $(\mathrm{CP})$, ether extract (EE), neutral detergent fiber, acid detergent fiber and acid detergent lignin contents.

Results: The contents of CP and EE increased, whereas all other components decreased, in proportion to LBY inclusion $(\mathrm{p}<0.01)$. The DM and OM contents gradually decreased in weeks 3 and $4(\mathrm{p}<0.05)$, while $\mathrm{EE}$ contents were lowest in week 0 . The $\mathrm{pH}$, ammonia nitrogen per total nitrogen $\left(\mathrm{NH}_{3}-\mathrm{N} / \mathrm{TN}\right)$ and $\mathrm{V}$-score in each mixture and storage period demonstrated superior fermentation quality ( $\mathrm{pH} \leq 4.2, \mathrm{NH}_{3}-\mathrm{N} / \mathrm{TN} \leq 12.5 \%$, and $\mathrm{V}$-score $\left.>90 \%\right)$. The $\mathrm{pH}$ increased and $\mathrm{NH}_{3}-\mathrm{N} / \mathrm{TN}$ decreased, with proportionate increases of LBY, whereas the $\mathrm{pH}$ decreased and $\mathrm{NH}_{3}-\mathrm{N} / \mathrm{TN}$ increased, as the storage periods were extended $(\mathrm{p}<0.01)$. Although IVGP decreased in proportion to the amount of LBY inclusion $(\mathrm{p}<0.01)$, in vitro organic matter digestibility (IVOMD) was unaffected by the mixture ratios. The highest IVGP and IVOMD were observed in week $0(\mathrm{p}<0.01)$.

Conclusion: The inclusion of LBY (as high as 30\%) into CVP improves the chemical composition of the mixture, thereby increasing the $\mathrm{CP}$ content, while decreasing IVGP, without decreasing fermentation quality and IVOMD. In addition, a preservation period of up to four weeks can guarantee superior fermentation quality in all types of mixtures. Therefore, we recommend limiting the use of CVP as a feed ingredient, given its low nutritional value and improving feed quality with the inclusion of LBY.

Keywords: Cassava Pulp; Chemical Composition; Fermentation Quality; In vitro Ruminal Fermentation; Liquid Brewer's Yeast

\section{INTRODUCTION}

The lack of a high quality diet to feed livestock has become a very urgent problem for small farmers in developing countries. A solution using a relatively high amount of commercial concentrate would be possible, if the farmers had access to such a concentrate. However, feedstuff concentrates are expensive, as most contain protein sources, such as soybean meal. Cheap by-products (and waste products) obtained from local industries have often been utilized by small farmers, living around the factories. Specific by-products obtained from the production 
of beer, such as brewers' grains and brewers dried yeast, have been used in animal feed $[1,2]$. Saccharomyces cerevisiae is the prevalent budding yeast microbe involved in brewing [3] and is considered to be a generally accepted alternative by-product for livestock feed, due to its high nutritional value [4]. Liquid brewer's yeast (LBY), obtained by removal of yeast after fermentation in the beer brewing process, contains at least $32 \%$ crude protein (CP) on a dry matter (DM) basis [5]. Compare to basic diets, supplementing LBY improved dry matter intake and resulted in more rapid gains, and there was no difference between yeast- and soybean- supplemented rations [6]. Furthermore, supplementary LBY ( $6 \%$ to $12 \% \mathrm{DM}$ ) in complete rations for lactating cows did not affect milk yield, composition or quality [7].

Consequently, small farmers in Thailand have approached the factories of beer manufactures to obtain LBY for dairy cattle feeding. One such factory in Northeast Thailand has a beer production capacity of 700 million liters per year [8]. It is thought that they generate about $1,000 \mathrm{~m}^{3} \mathrm{LBY}$ per month and about $40 \%$ of this amount is received by farmers within the vicinity (unconfirmed estimate). Cassava (Manihot esculenta Crantz.) pulp (CVP) is produced as a by-product of starch manufacturing, and is a major biomass resource in animal feedstock. In 2013, approximately 15 million tons of fresh cassava roots were extracted from the fields in Northeast Thailand [9]. Approximately $10 \%$ to $15 \%$ of the resulting cassava pulp was utilized as livestock feed [10], and contained $17 \%$ to $19 \%$ DM [11], as well as high rates of starch and cellulose (approximately $60 \%$ and $20 \%$ on a DM basis, respectively [12]). However the CP content, $2.4 \% \mathrm{DM}$, was relatively low [13].

Several studies have been conducted to enrich the $\mathrm{CP}$ content of cassava pulp through various treatments in solid-state fermentation, such as yeast culturing [14] and microorganic fermentation $[15,16,17]$. The use of LBY, a liquid state fermentation product mixed with CVP, offers farmers enriched protein at lower overall feed costs. Since both LBY and CVP have high moisture contents, the livestock feed must be stored in bunkers after mixing, in preparation for transportation to distant farmers. Therefore, maintaining an optimum ratio of LBY and CVP during the necessary storage periods is critical for its practical use in farms. This study aims to evaluate the chemical composition, fermentation quality and in vitro ruminal fermentation of various ratios and storage periods of LBY mixed with CVP.

\section{MATERIALS AND METHODS}

\section{Sample preparation}

Experiments were conducted at Khon Kaen Animal Nutrition

Research and Development Center, in May 2013. Fresh LBY and CVP, obtained from a brewery and a starch factory, respectively in the Khon Kaen Province, were collected in four mixtures (LBY0, LBY10, LBY20, and LBY30), in LBY:CVP ratios of 0:100,
10:90, 20:80, and 30:70, respectively, on a fresh matter basis. Twenty composites of $500 \mathrm{~g}$ were made from each mixture and packed into $15 \times 23 \mathrm{~cm}$ plastic bags. The bags were sealed using a vacuum sealer and stored at room temperature $\left(30^{\circ} \mathrm{C}\right.$ to $\left.32^{\circ} \mathrm{C}\right)$. Four bags from each mixture were opened for analysis at 0,1 , 2,3 , and 4 weeks after storage.

\section{Chemical analyses}

A $50 \mathrm{~g}$ sample from each composite was homogenized with $100 \mathrm{~mL}$ of distilled water and stored overnight in a refrigerator, at $4^{\circ} \mathrm{C}$. The homogenate was then filtered through Whatman no. 5 filter paper for $\mathrm{pH}$, ammonia nitrogen $\left(\mathrm{NH}_{3}-\mathrm{N}\right)$, lactic acid (LA) and volatile fatty acid (VFA) determination. The $\mathrm{pH}$ was measured by $\mathrm{pH}$ meter (D-22; Horiba, Kyoto, Japan) and the $\mathrm{NH}_{3}-\mathrm{N}$ content was determined using a steam distillation technique [18]. The remaining sample mixture was oven dried at $60^{\circ} \mathrm{C}$ for $48 \mathrm{~h}$. The dried samples were ground to pass through a $1 \mathrm{~mm}$ screen for subsequent analyses of DM (on oven drying procedure at $135^{\circ} \mathrm{C}$ for $2 \mathrm{~h}$ ), $\mathrm{CP}$, ether extract (EE) and crude ash (CA), according to the Association of Official Analytical Chemists [19]. The organic matter (OM) was calculated as lost weight through ashing. Neutral detergent fiber (NDFom) and acid detergent fiber (ADFom), expressed exclusive of residual ash without amylase treatment and acid detergent lignin (ADL) were determined according to the methods of [20]. LA and VFA concentrations were determined by using high performance liquid chromatography (LC-20A; Shimadzu, Kyoto, Japan), using a Nova-pak C18 steel column: $3.9 \times 300 \mathrm{~mm}$, according to the methods of [21]. The flow rate was $0.5 \mathrm{~mL} / \mathrm{min}$ and the wavelength of UV detector was $210 \mathrm{~nm}$. To assess the quality of the mixture, the V-scores were calculated from the $\mathrm{NH}_{3}-\mathrm{N} / \mathrm{TN}$ and VFA concentrations [18]. According to the scoring criteria, the samples were divided into three ranks: superior (81 to 100), $\operatorname{good}(60$ to 80$)$ and bad $(<60)$ [22].

\section{In vitro gas production analyses}

Buffered mineral solution [23] was prepared and placed in a water bath at $39^{\circ} \mathrm{C}$ under continuous $\mathrm{CO}_{2}$ flushing. Rumen fluid was collected from two fistulated Brahman crossbred cattle, prior to their morning feeding. The dried and ground samples, were weighted (200 mg each) and inserted into two $100 \mathrm{~mL}$ calibrated glass syringes. The samples were incubated in vitro with the buffered rumen fluid (30 $\mathrm{mL}$ each) in calibrated glass syringes, duplicated for each sample. The ratio of rumen fluid to buffered mineral solution was 1:2. Gas production volume was recorded at $6,12,24$, and $48 \mathrm{~h}$ of incubation and gas production of the incubated mixtures was calculated for mean blank value over a $24 \mathrm{~h}$ period [23], through the following equations.

$$
\mathrm{GP}=\left(\mathrm{V}_{24}-\mathrm{V}_{0}-\mathrm{GP}_{0}\right) / \text { Weight in mg DM }
$$

Where GP = gas production $(\mathrm{mL} / \mathrm{mg} \mathrm{DM}), \mathrm{V}_{0}=$ volume at 
$0 \mathrm{~h}(\mathrm{~mL}), \mathrm{V}_{24}=$ volume at $24 \mathrm{~h}(\mathrm{~mL})$, and $\mathrm{GP}_{0}=$ the mean blank value at $0 \mathrm{~h}(\mathrm{~mL})$.

Organic matter digestibility (OMD) and metabolizable energy (ME) were estimated [23], in the $24 \mathrm{~h}$ gas production period, through the following equations.

$$
\mathrm{OMD}(\%)=9.00+0.9991 \mathrm{GP}+0.0595 \mathrm{XP}+0.0181 \mathrm{XA}
$$

$\mathrm{ME}(\mathrm{MJ} / \mathrm{kg} \mathrm{DM})$

$=1.06+0.1570 \mathrm{GP}+0.0084 \mathrm{XP}+0.0220 \mathrm{XE}-0.0081 \mathrm{XA}$

Where $\mathrm{GP}=$ gas production at $24 \mathrm{~h}(\mathrm{~mL} / 200 \mathrm{mg} \mathrm{DM}), \mathrm{XP}$ $=\mathrm{CP}$ content $(\mathrm{g} / \mathrm{kg} \mathrm{DM}), \mathrm{XE}=\mathrm{EE}$ content $(\mathrm{g} / \mathrm{kg} \mathrm{DM})$, and $\mathrm{XA}=$ crude ash content $(\mathrm{g} / \mathrm{kg} \mathrm{DM})$.

\section{Statistical analysis}

Data were analyzed with repeated measures, using the PROC MIXED procedure of SAS [24], through the following model: $Y_{i j k}=\mu+M_{i}+S_{j}+(M S)_{i j}+e_{i j k}$, where $Y_{i j k}$ is the observed value, $\mu$ is overall mean, $M_{i}$ is the effect associated with the mixture ratio, $S_{j}$ is the effect associated with the storage periods, $(M S)_{i j}$ is the interaction effect between mixture ratio and storage period and $e_{i j k}$ is residual (s).

The orthogonal polynomial contrast examined linear and quadratic responses to the LBY mixture ratios and storage periods and Duncan's new multiple range test detected the differences between the means of each data analysis [25]. Correlation coefficients among parameters from chemical composition, gas production, OMD and ME were calculated through Pearson's correlation. Significances were declared at $\mathrm{p}<0.05$.

\section{RESULTS}

Chemical composition of the mixtures of liquid brewer's yeast and cassava pulp

The chemical compositions of fresh LBY and CVP prior to mixing are shown in Table 1. The $\mathrm{pH}$, and $\mathrm{DM}, \mathrm{OM}, \mathrm{CP}$, and EE contents of the LBY were 5.3 , and $12.0 \%, 92.0 \%, 48.3 \%$, and $0.7 \%$ on a DM basis, respectively. The NDFom, ADFom and ADL contents were undetected in the LBY. The CVP displayed $\mathrm{pH}$, and DM, OM, CP, EE, NDFom, ADFom, and ADL contents at 3.7 , and $18.6 \%, 96.8 \%, 2.9 \%, 0.4 \%, 36.6 \%, 24.5 \%$, and $4.9 \%$, respectively.
Changes within the chemical composition of the four mixture ratios and five storage periods are shown in Table 2. Among the mixture ratio means, the $\mathrm{DM}, \mathrm{OM}, \mathrm{CP}, \mathrm{EE}, \mathrm{NDF}$, ADFom, and $\mathrm{ADL}$ of the four mixtures ranged $16.5 \%$ to $18.0 \%, 95.7 \%$ to $96.6 \%, 3.2 \%$ to $14.1 \%, 0.4 \%$ to $0.5 \%, 32.0 \%$ to $36.2 \%, 21.1 \%$ to $24.8 \%$, and $3.8 \%$ to $4.9 \%$, respectively. The results were dependent on the differences in chemical composition and mixture ratio within the LBY and CVP. Increasing the level of LBY linearly increased CP and EE contents, and decreased other chemical compositions $(p<0.01)$. For the means of storage period, the $\mathrm{DM}$ and $\mathrm{OM}$ contents linearly and quadratically decreased, while the EE and ADFom contents increased linearly, as the storage periods progressed $(\mathrm{p} \leq 0.01)$. The interaction effects between mixture ratios and storage periods on $\mathrm{DM}, \mathrm{OM}, \mathrm{CP}$, $\mathrm{EE}$, and ADFom are identified in Table 2.

\section{Fermentation quality in the liquid brewer's yeast and cassava pulp mixtures}

Table 3 shows the changes in $\mathrm{pH}, \mathrm{NH}_{3}-\mathrm{N} / \mathrm{TN}, \mathrm{LA}$, and VFA concentrations of the mixture during the storage period $(\mathrm{p} \leq 0.01)$. All parameters were quadratically affected by the mixture ratios, and acute increases in $\mathrm{pH}$, acetic and butyric contents, as well as decreases in $\mathrm{NH}_{3}-\mathrm{N} / \mathrm{TN}$, LA contents and V-scores were observed in the progression from LBY0 to LBY10. More specifically, the quadratically increases of acetic and propionic acids and the linear decrease in $\mathrm{V}$-scores were more severe in the later preservation periods. The interaction effects between the mixture ratios and storage periods were observed in $\mathrm{pH}, \mathrm{LA}$, acetic, propionic and butyric acid contents, and V-score $(\mathrm{p}<0.01)$, (Figure 1).

\section{Gas production, estimated OMD, ME, and their relationship with chemical composition}

Gas production from the mixture of LBY and CVP with different mixture ratios, storage periods and post incubation parameters, described as OMD and ME, are shown in Table 4. Comparing the mixture ratio means, the gas production of LBY0 and LBY10 differed only slightly $(\mathrm{p}<0.01)$, yet were higher than that of LBY20 and LBY30, at 6 and $12 \mathrm{~h}$ of incubation time. LBY0 reported the highest value at 24 and $48 \mathrm{~h}$. The gas production at $48 \mathrm{~h}$ decreased quadratically with the inclusion of LBY. As indicated within the storage period means, gas production decreased as the storage period increased, especially within weeks 0 to 1 . The

Table 1. pH and chemical composition of experimental diets

\begin{tabular}{|c|c|c|c|c|c|c|c|c|}
\hline Item & $\mathrm{pH}$ & DM & $\mathrm{OM}^{1)}$ & $\mathrm{CP}^{1)}$ & $\mathrm{EE}^{1)}$ & NDFom ${ }^{1)}$ & ADFom $^{1)}$ & $A D L^{1)}$ \\
\hline Liquid brewer's yeast & 5.3 & 12.0 & 92.0 & 48.3 & 0.7 & ND & ND & ND \\
\hline Cassava pulp & 3.7 & 18.6 & 96.8 & 2.9 & 0.4 & 36.6 & 24.5 & 4.9 \\
\hline
\end{tabular}

DM, dry matter; OM, organic matter; $C$, crude protein; $\mathrm{EE}$, ether extract; NDFom, neutral detergent fiber expressed exclusive of residual ash; ADFom, acid detergent fiber expressed exclusive of residual ash; $A D L$, acid detergent lignin; ND, not detected.

1) On a dry matter basis. 
Table 2. Chemical composition of mixture of liquid brewer's yeast (LBY) and cassava pulp (CVP) at different ratios and storage periods (\%)

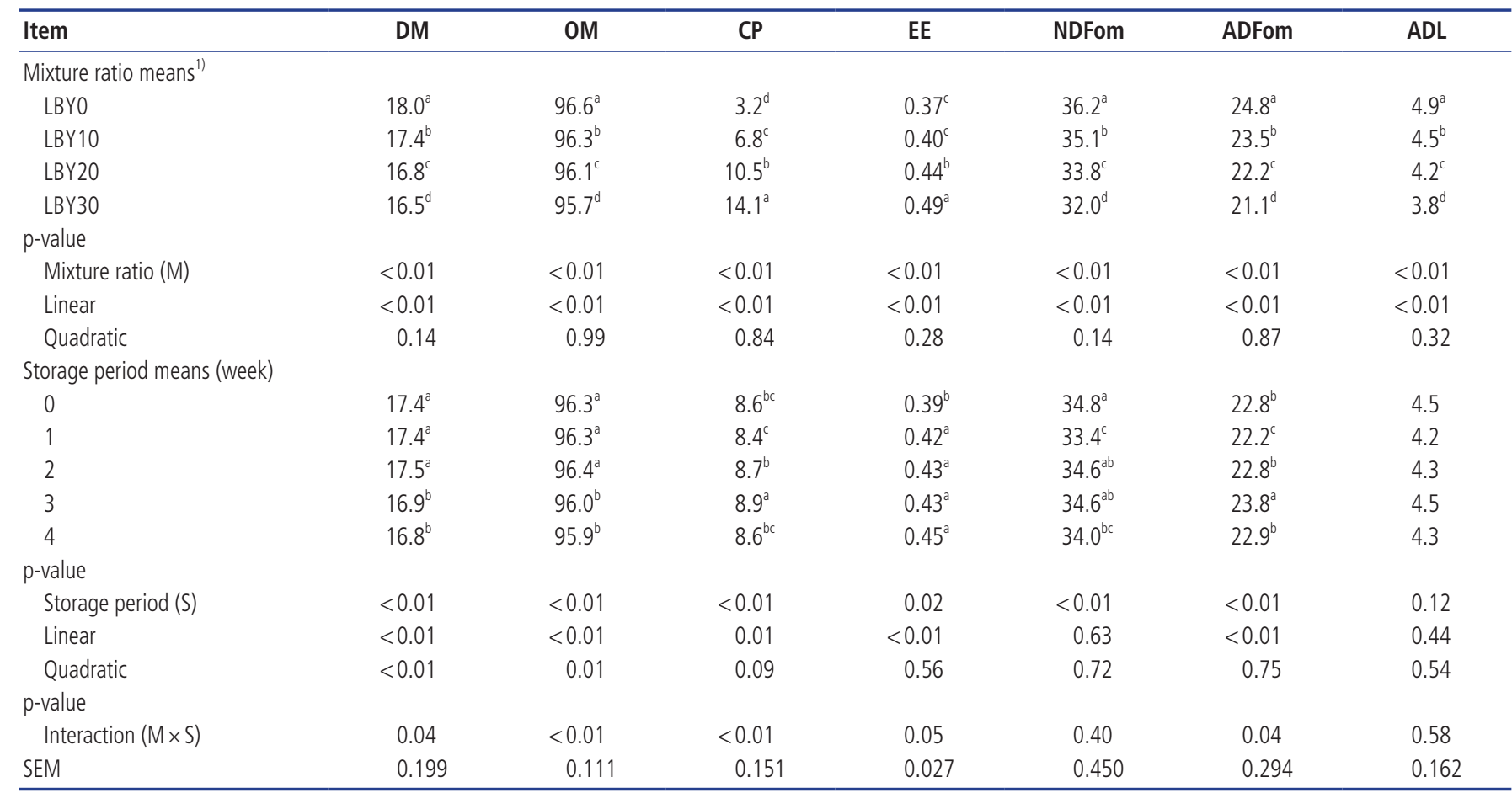

DM, dry matter; OM, organic matter; $C P$, crude protein; EE, ether extract; NDFom, neutral detergent fiber expressed exclusive of residual ash; ADFom, acid detergent fiber expressed exclusive of residual ash; $A D L$, acid detergent lignin; SEM, standard error of the means.

1) $L B Y 0,10,20$ and 30, mixture ratios of $L B Y: C V P$ at $0: 100,10: 90,20: 80$ and 30:70, respectively, on a fresh matter basis.

${ }^{\mathrm{a}-\mathrm{d}}$ Means with different superscripts within columns significantly differed $(p<0.05)$.

Table 3. Fermentation quality of mixture of liquid brewer's yeast (LBY) and cassava pulp (CVP) at different ratios and storage periods

\begin{tabular}{|c|c|c|c|c|c|c|c|}
\hline Item & $\mathrm{pH}$ & $\mathrm{NH}_{3}-\mathrm{N} / \mathrm{TN}(\%)$ & LA & $\mathrm{AA}$ & $\mathrm{PA}$ & BA & V-score \\
\hline \multicolumn{8}{|l|}{ Mixture ratio means ${ }^{1)}$} \\
\hline LBY 10 & $3.74^{c}$ & $4.54^{b}$ & $0.90^{c}$ & $0.25^{b}$ & $0.11^{\mathrm{b}}$ & $0.07^{\mathrm{a}}$ & $92.6^{b}$ \\
\hline LBY20 & $3.84^{b}$ & $4.03^{c}$ & $1.03^{b}$ & $0.29^{\mathrm{a}}$ & $0.10^{c}$ & $0.06^{b}$ & $93.7^{b}$ \\
\hline LBY30 & $3.91^{\mathrm{a}}$ & $4.04^{c}$ & $1.06^{b}$ & $0.25^{b}$ & $0.14^{\mathrm{a}}$ & $0.07^{\mathrm{a}}$ & $92.9^{b}$ \\
\hline Linear & $<0.01$ & $<0.01$ & $<0.01$ & $<0.01$ & $<0.01$ & $<0.01$ & $<0.01$ \\
\hline Quadratic & $<0.01$ & 0.01 & $<0.01$ & 0.01 & 0.01 & $<0.01$ & 0.01 \\
\hline \multicolumn{8}{|c|}{ Storage period means (week) } \\
\hline 0 & $3.84^{\mathrm{a}}$ & $2.75^{\mathrm{e}}$ & $0.59^{d}$ & $0.07^{d}$ & $0.07^{d}$ & $0.05^{b}$ & $96.4^{\mathrm{a}}$ \\
\hline 1 & $3.75^{\mathrm{c}}$ & $3.67^{d}$ & $1.22^{b}$ & $0.16^{c}$ & $0.06^{\mathrm{e}}$ & $0.05^{b}$ & $95.9^{\mathrm{a}}$ \\
\hline Storage period (S) & $<0.01$ & $<0.01$ & $<0.01$ & $<0.01$ & $<0.01$ & $<0.01$ & $<0.01$ \\
\hline Linear & $<0.01$ & $<0.01$ & $<0.01$ & $<0.01$ & $<0.01$ & 0.72 & $<0.01$ \\
\hline Quadratic & 0.66 & $<0.01$ & $<0.01$ & $<0.01$ & $<0.01$ & $<0.01$ & 1.00 \\
\hline \multicolumn{8}{|l|}{$p$-value } \\
\hline Interaction $(\mathrm{M} \times \mathrm{S})$ & $<0.01$ & 0.30 & $<0.01$ & $<0.01$ & $<0.01$ & $<0.01$ & $<0.01$ \\
\hline SEM & 0.023 & 0.301 & 0.088 & 0.027 & 0.004 & 0.009 & 0.796 \\
\hline
\end{tabular}

$\mathrm{NH}_{3}$-N/TN, ammonia nitrogen/total nitrogen; LA, lactic acid; $\mathrm{AA}$, acetic acid; PA, propionic acid; BA, $\mathrm{n}$ - and i-butyric acid; SEM, standard error of the means.

1) $L B Y 0,10,20$, and 30, mixture ratios of $L B Y: C V P$ at $0: 100,10: 90,20: 80$, and 30:70, respectively, on a fresh matter basis.

a-e Means with different superscripts within columns significantly differed $(p<0.05)$. 

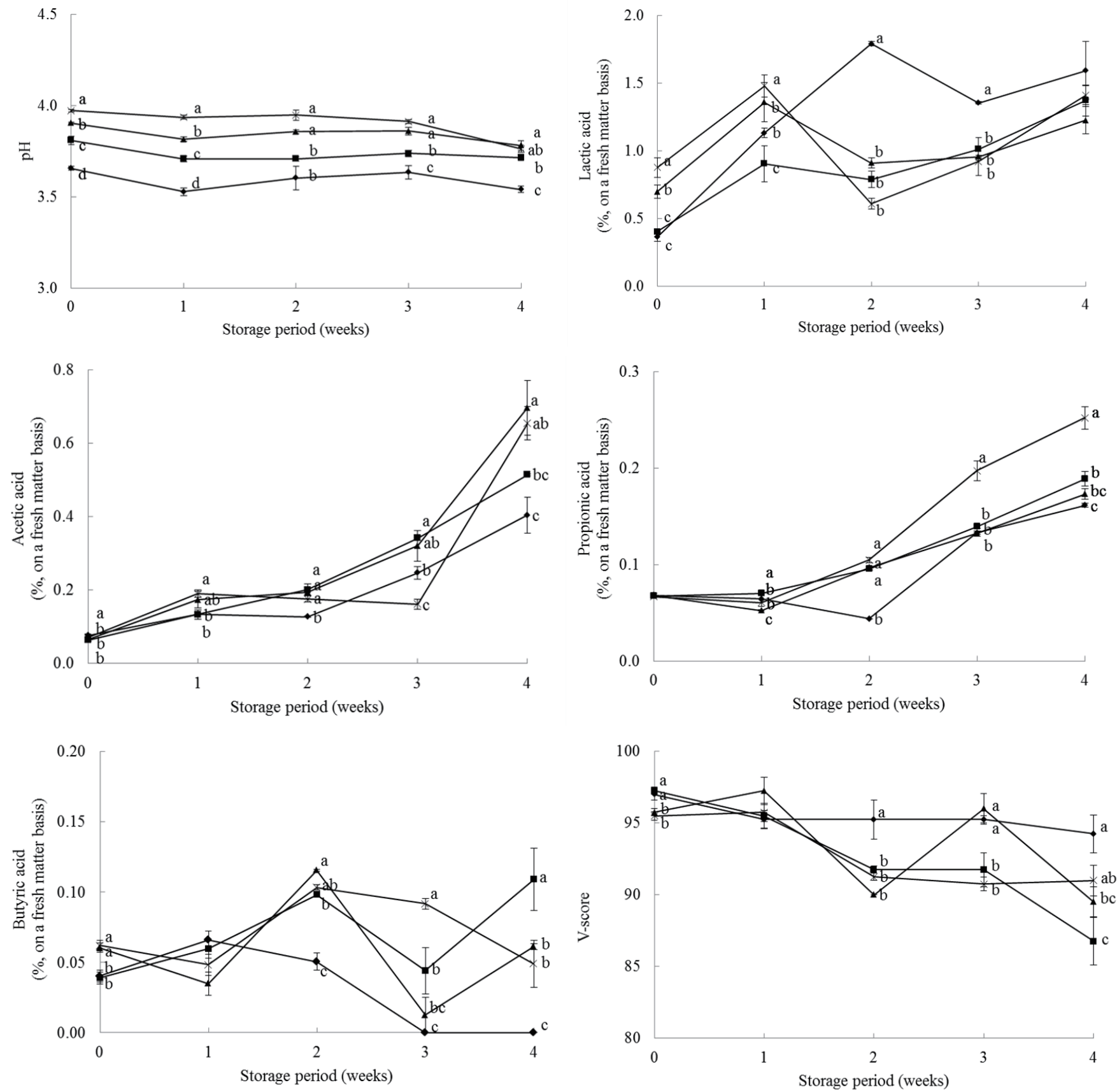

Figure 1. pH, lactic acid, acetic acid, propionic acid, butyric acid and V-score showing interaction effects between mixture ratio and storage period. Bars are standard error of the means. Symbols: $\downarrow$ LBYO; $\mathbf{E}, \mathrm{LBY} 10 ; \boldsymbol{\Lambda}, \mathrm{LBY} 20 ; \times$, LBY30. LBY0, 10, 20, and 30, mixture ratios of LBY:CVP at 0:100, 10:90, 20:80, and 30:70, respectively, on a fresh matter basis. LBY, liquid brewer's yeast; CVP, cassava pulp. Different letters indicate a significant difference between treatments in each storage period $(p<0.05)$.

interaction effects between the mixture ratios and storage periods were observed in the 6,24 , and $48 \mathrm{~h}$ (Table 4 ). Among the four mixture ratio means, estimated $\mathrm{OMD}$ and $\mathrm{ME}$ ranged from $77.4 \%$ to $79.7 \%$ and 11.4 to $11.8 \mathrm{MJ} / \mathrm{kg} \mathrm{DM}$, respectively, each scoring lowest in LBY20 ( $<<0.05)$. Figure 2 provides the interaction effects of the mixture ratios and storage periods for both OMD and ME $(\mathrm{p}<0.01)$.

The correlation coefficients between chemical compositions, $\mathrm{OMD}, \mathrm{ME}$, and in vitro gas production (IVGP) are shown in
Table 5. DM and OM contents were positively correlated at 6 $\mathrm{h}(\mathrm{p}<0.05), 12$ and $24 \mathrm{~h}(\mathrm{p}<0.01)$ and $48 \mathrm{~h}(\mathrm{p}<0.05)$. NDFom and non-fiber carbohydrate (NFC) contents were positively correlated at 12,24 , and $48 \mathrm{~h}(\mathrm{p}<0.01)$. The $\mathrm{NH}_{3}-\mathrm{N} / \mathrm{TN}$ contents at $6 \mathrm{~h}$ incubation were also positively correlated $(\mathrm{p}<0.01)$. Contrastingly, the $\mathrm{CP}$ content was negatively correlated at $12 \mathrm{~h}(\mathrm{p}<$ $0.05)$, and at 24 and $48 \mathrm{~h}(\mathrm{p}<0.01)$. EE content was also negatively correlated at $6 \mathrm{~h}(\mathrm{p}<0.05), 12$ and $24 \mathrm{~h}(\mathrm{p}<0.01)$ and 48 $\mathrm{h}(\mathrm{p}<0.05)$. OMD and ME did not significantly correlate with 
Table 4. Gas production, organic matter digestibility and metabolizable energy of mixture of liquid brewer's yeast (LBY) and cassava pulp (CVP) at different ratios and storage periods

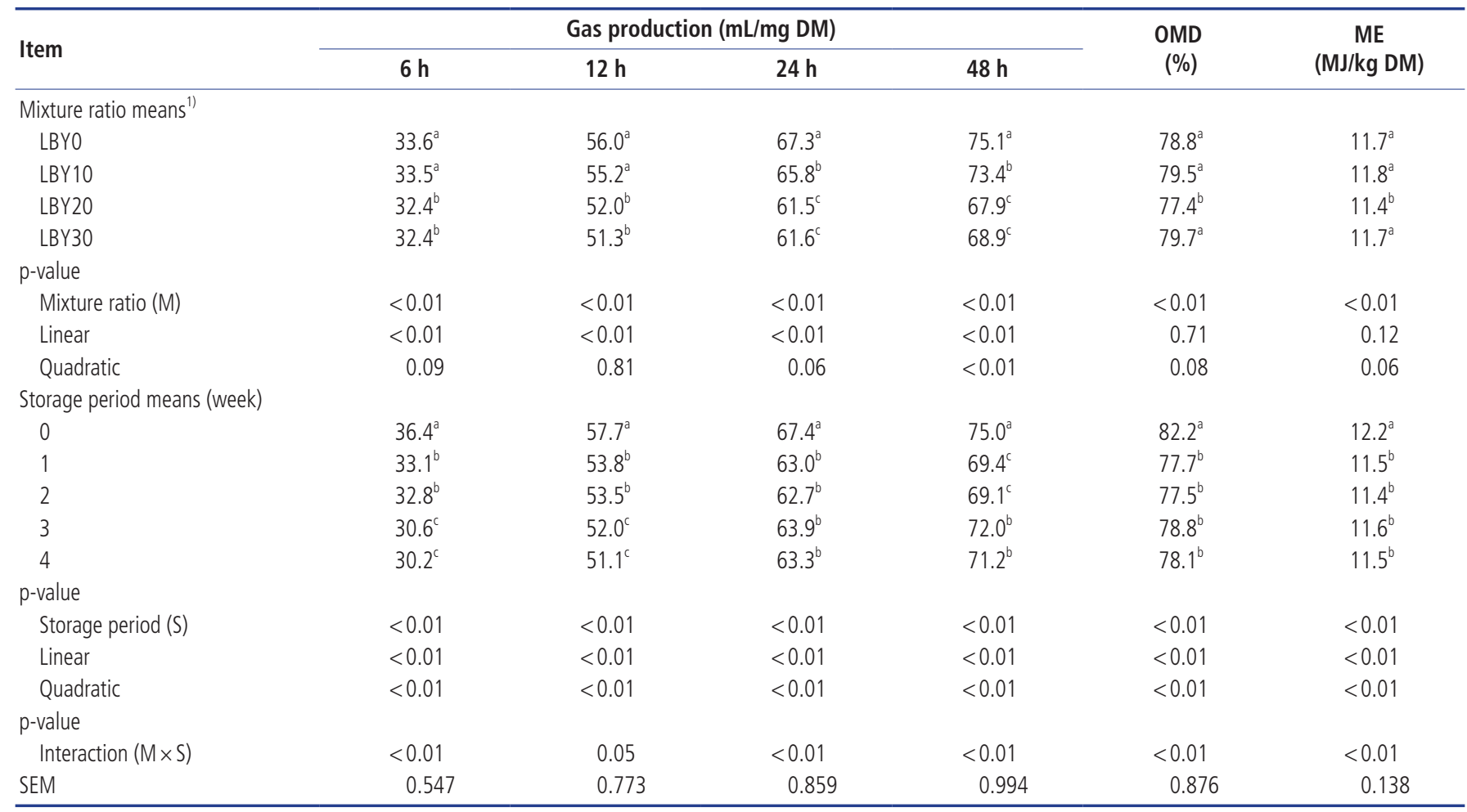

$\mathrm{OMD}$, organic matter digestibility; ME, metabolizable energy; SEM, standard error of the means.

1) $L B Y O, 10,20$, and 30, mixture ratios of $L B Y: C V P$ at $0: 100,10: 90,20: 80$, and 30:70, respectively, on a fresh matter basis.

${ }^{a-c}$ Means with different superscripts within columns significantly differed $(p<0.05)$.

the chemical composition.

\section{DISCUSSION}

Chemical composition and fermentation characteristics Comparatively, the LBY in this experiment had lower DM and $\mathrm{CP}$ contents than the compositions within the study conducted by [26], (14.4\% and $53.0 \%)$, yet fell within the same range of those within the study conducted by [6], (10.8\% to $13.4 \%$ and $43.1 \%$ to $51.4 \%)$. The CVP was highly acidic, and the $\mathrm{pH}$ (3.66) was lower than that reported by [11], (3.89). These variations may be a result of different materials, plant locations and processing. However, the CP, EE, NDFom, and ADFom contents of CVP in this study were similar to the sample means of a report of three starch factories in Northeast Thailand, by [13], at 2.4\%, $0.4 \%, 40.1 \%$, and $25.3 \%$ on a DM basis, respectively.

In this study, $\mathrm{CP}$ content increased $(\mathrm{p}<0.01)$ with the amount of LBY inclusion in the mixture from $3 \%$ to $14 \%$, with the $0 \%$ to $30 \%$ proportion of LBY (Table 2), which attributed to a higher CP content in LBY than in CVP. The linear declines of DM, NDFom, ADFom, and ADL contents from LBY10 to LBY30 were caused by the decreases in the proportions of CVP, which contained a higher ratio of DM and fiber contents, than LBY.

Through prolonged storage periods, the contents of DM and
$\mathrm{OM}$ in the mixture declined in contrast with the increase in $\mathrm{CP}$ content, which agreed with the findings of [27]. The decline of $\mathrm{DM}$ and $\mathrm{OM}$ may have been due to the generation of moisture and loss of fermentation substrates, such as NFC.

The changes in fermentation characteristics indicate that LBYO had the lowest $\mathrm{pH}$, given the strong acidic content of CVP, due to the starch extraction process [10]. While $\mathrm{NH}_{3}-\mathrm{N} / \mathrm{TN}$ ranked the least amount of content within the mixture, it was highest in LBY0, which may have been due to the relatively lower CP content in LBY0. [28] reported a CVP which an NFC as high as $25 \%$ on a DM basis. In the present study, the CVP's NFC content was estimated as $56.8 \%$ on a DM basis, through the equation $\mathrm{NFC}=100-(\mathrm{CP}+\mathrm{EE}+\mathrm{NDFom}+\mathrm{CA})$. The higher LA content may have been a result of the higher NFC content in CVP as a substrate for the fermentation of LA.

During preservation, the $\mathrm{pH}$ of each treatment decreased from weeks 0 to 4 . These results coincide with the study of [11], which found that the $\mathrm{pH}$ of CVP continuously decreased from 3.89 to 3.40 during 28 days of ensiling. The $\mathrm{NH}_{3}-\mathrm{N} / \mathrm{TN}$, as well as the acetic and propionic acid contents, gradually increased during the preservation of all LBY levels. However, the $\mathrm{NH}_{3}-\mathrm{N} /$ TN content increased only slightly, at $2.8 \%$ to $5.9 \%$. According to [29], an $\mathrm{NH}_{3}-\mathrm{N}$ content of less than $10 \%$ of total nitrogen has been identified as a characteristic of well-preserved silage. Pre- 

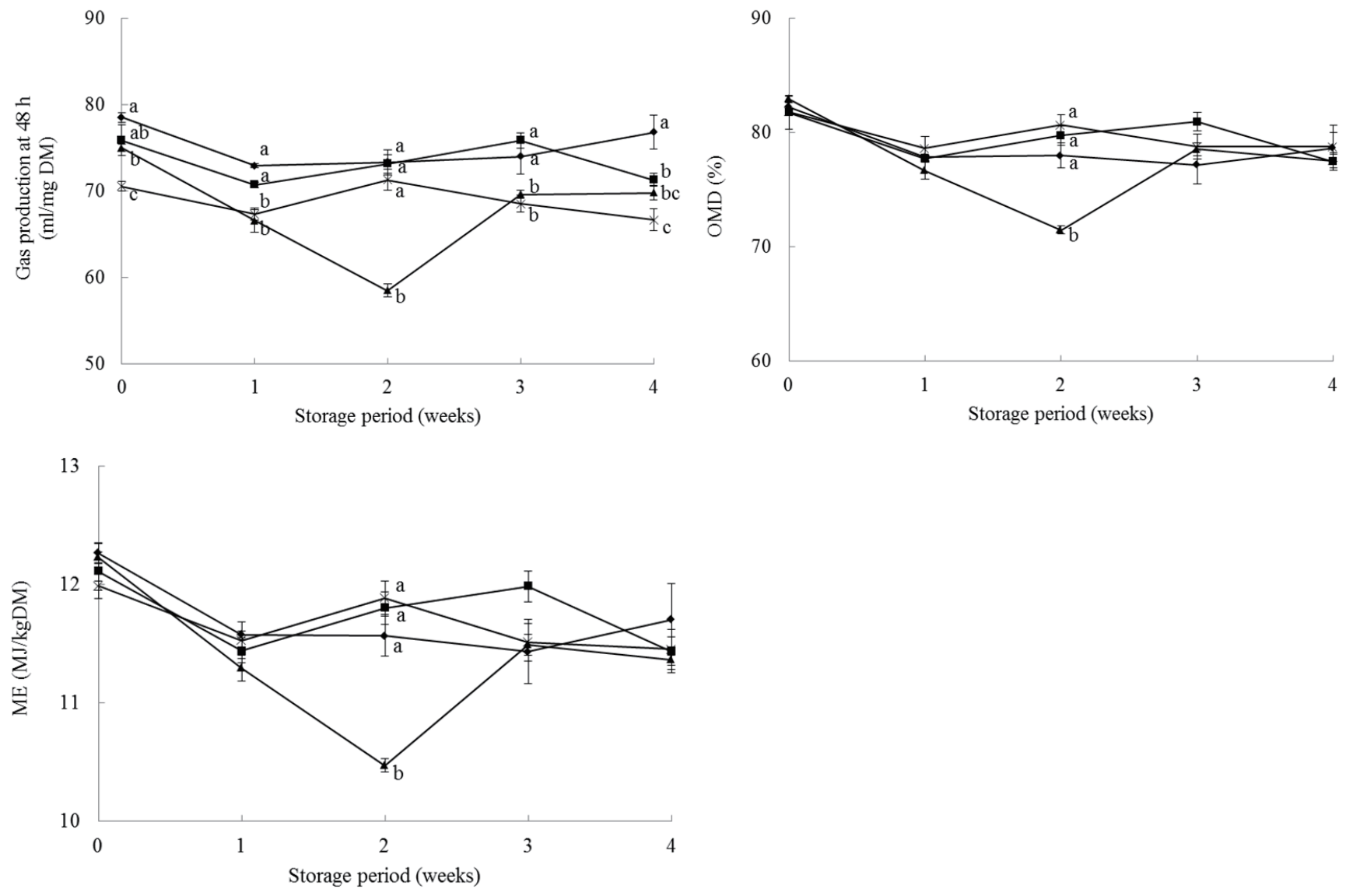

Figure 2. Gas production at $48 \mathrm{~h}$, organic matter digestibility (OMD) and metabolizable energy (ME) showing interaction effects between mixture ratio and storage period. Bars are standard error of the means. Symbols: $\downarrow$, LBY; $\mathbf{E}, \mathrm{LBY} 10 ; \boldsymbol{\Delta}$, LBY20; $\times$, LBY30. LBYO, 10, 20, and 30, mixture ratios of LBY:CVP at 0:100, 10:90, 20:80, and 30:70, respectively, on a fresh matter basis. LBY, liquid brewer's yeast; CVP, cassava pulp. Different letters indicate a significant difference between treatments in each storage period ( $p<0.05$ ).

vious research on ensiling wet by-products have also indicated low propionic acid contents and very small (if any) quantities of butyric acid [30,31]. The $\mathrm{V}$-score means in all mixture ratios and storage periods were higher than $90 \%$, which suggested that the mixture had superior fermentation quality in all pres-

Table 5. Correlation coefficients $(r)$ between chemical compositions, in vitro gas production, organic matter digestibility and metabolizable energy

\begin{tabular}{|c|c|c|c|c|c|c|}
\hline \multirow{2}{*}{ Item } & \multicolumn{4}{|c|}{ Gas production (mL/mg DM) } & \multirow{2}{*}{$\begin{array}{l}\text { OMD } \\
(\%)\end{array}$} & \multirow{2}{*}{$\begin{array}{c}\text { ME } \\
(\mathrm{MJ} / \mathrm{kg} \mathrm{DM})\end{array}$} \\
\hline & $6 \mathrm{~h}$ & $12 \mathrm{~h}$ & $24 \mathrm{~h}$ & $48 \mathrm{~h}$ & & \\
\hline DM & $0.45^{*}$ & $0.72^{* *}$ & $0.60 * *$ & $0.46^{*}$ & 0.00 & 0.17 \\
\hline OM & $0.51^{*}$ & $0.66^{* *}$ & $0.57^{* *}$ & $0.47^{*}$ & -0.02 & 0.15 \\
\hline$C P$ & -0.30 & $-0.62^{*}$ & $-0.70^{* *}$ & $-0.63^{* *}$ & 0.01 & -0.16 \\
\hline $\mathrm{EE}$ & $-0.54^{*}$ & -0.70 ** & $-0.65^{* *}$ & $-0.55^{*}$ & -0.14 & -0.26 \\
\hline NDFom & 0.36 & $0.65^{* *}$ & $0.74 * *$ & $0.69 * *$ & 0.11 & 0.27 \\
\hline NFC & 0.29 & $0.59^{* *}$ & $0.64^{* *}$ & $0.55^{*}$ & -0.08 & 0.09 \\
\hline $\mathrm{NH}_{3}-\mathrm{N} / \mathrm{TN}$ & $0.57^{* *}$ & -0.36 & 0.01 & 0.12 & -0.32 & -0.27 \\
\hline
\end{tabular}

$\mathrm{OMD}$, organic matter digestibility; ME, metabolizable energy; $\mathrm{DM}$, dry matter; $\mathrm{OM}$, organic matter: $C P$, crude protein; $E E$, ether extract; NDFom, neutral detergent fiber expressed exclusive of residual ash; NFC, non fiber carbohydrate (100-[CP+EE+NDF+crude ash]); $\mathrm{NH}_{3}-\mathrm{N} / \mathrm{TN}$, ammonia nitrogen/total nitrogen.

${ }^{*} p<0.05 ;{ }^{* *} p<0.01$ ervation periods [22].

\section{Gas production, estimated $\mathrm{OMD}, \mathrm{ME}$ and their relationship with chemical composition}

The gas production technique is widely used for evaluating nutritive values in ruminant feeds. In this study, each mixture had high GP early in the fermentation period, which may have been due to its low fiber content (Table 4). The highest GP of LBYO (reduced with the inclusion of LBY) may also be explained by the low fiber content. However, GP reduced with increased $\mathrm{CP}$ content, as well as with decreased DM and NDFom contents (Table 4). These same results were initiallty found in the study of [32], which suggested that GP reduced with increased CP levels. The estimated $\mathrm{ME}$ values of the four mixture ratios, ranging from 11.4 to $11.7 \mathrm{MJ} / \mathrm{kg} \mathrm{DM}(\mathrm{p}<0.05)$, were higher than those reported in the studies of [33], (10.89 MJ/kg DM) and [34], (10.04 MJ/kg DM).

The gas production parameters suggest differences in nutritive values that are closely related to their chemical composition [35]. In this study, we found strong negative correlations between GP and the contents of CP and EE (Table 5), consistent with the 
study of [36]. While, the contents of DM, OM, NDFom, and NFC were positively correlated with GP, it is likely that NDFom and NFC in the mixture were highly fermentable, demonstrated by low-NDF fall-grown oat forages [37]. The $\mathrm{NH}_{3}-\mathrm{N} / \mathrm{TN}$ content was positively correlated with GP in the first $6 \mathrm{~h}$ of incubation, which might have reflected the synchronizing fermentable nitrogen with carbohydrates, present in early fermentation. The OMD and ME, however, did not significantly correlated with any chemical composition.

We found that the inclusion of LBY (up to 30\%) into CVP can significantly improve the chemical composition of a feed mixture. A remarkable increase in $\mathrm{CP}$ content with decreased IVGP was achieved, with acceptable fermentation quality and without decreasing in vitro organic matter digestibility. In addition, we determined that a preservation period of up to four weeks could assure superior fermentation quality in all types of mixtures. Therefore, a low nutritive value of livestock feed, due to the limitation of CVP as a feed ingredient, can be instantly improved by the inclusion of LBY.

\section{CONFLICT OF INTEREST}

We certify that there is no conflict of interest with any financial organization regarding the material discussed in the manuscript.

\section{ACKNOWLEDGMENTS}

This study was financially supported by Agricultural Research Development Agency (Public Organization), Thailand.

\section{REFERENCES}

1. Aliyu S, Bala M. Brewer's spent grain: A review of its potentials and applications. Afr J Biotechnol 2011;10:324-31.

2. Levic J, Djuragic O, Sredanovic S. Use of new feed from brewer byproducts for breeding layers. Rom Bio Lett 2010;15:5559-65.

3. Manzano M, Giusto C, Bartolomeoli I, Buiatti S, Comi G. Microbiological analyses of dry and slurry yeasts for brewing. J Inst Brew 2005;111:203-8.

4. Bruning CL, Yokoyama MT. Characteristics of live and killed brewer's yeast slurries and intoxication by intraruminal administration to cattle. J Anim Sci 1987;66:585-91.

5. Linton JH. Nutritional evaluation of brewery by-products. Review of nutrition papers from Brewers Feed Conference. Feedstuffs 1977; $51: 8$.

6. Grieve DG. Feed intake and growth of cattle fed liquid brewer's yeast. Can J Anim Sci 1979;59:89-94.

7. Steckley JD, Grieve DG, Macleod GK, Moran Jr ET. Brewer's yeast slurry. II. A source of supplementary protein for lactating dairy cattle. J Dairy Sci 1979;62:947-53.

8. KKB. Khon Kaen Brewery [Internet]. History [cited 2015 Feb 25]. Available from: http://khonkaenbrewery.co.th/index. php? route= about/about

9. OAE [Internet]. Office of Agricultural Economics [cited $2014 \mathrm{Nov}$ 5]. Available from:http://www.oae.go.th/download/ prcai/ DryCrop/ cassava.pdf

10. Yimmongkol S. Research and development projects on improvement of the potential use of dried cassava pulp and cassava leaf meal in concentrate of feedlot cattle. [Ph.D. thesis]. Bangkok, Thailand: Kasetsart University; 2009.

11. Jintanawit W, Juttupornpong S, Markranit R, Srimongcholngam S, Viwatwongwana N. A study of changing of population of lactic acid bacteria and yeast during ensilaging of cassava pulp. Proceedings of the 44th Kasetsart University Annual Conference, 2006; 2006 Jan 30-Feb 2: Kasetsart University, Bangkok, Thailand: Kasetsart University; 2006. pp. 131-7.

12. Kosugi A, Kondo A, Ueda M, et al. Production of ethanol from cassava pulp via fermentation with a surface-engineered yeast strain displaying glucoamylase. Renew Energy 2009;34:1354-8.

13. Kosoom W, Charoenwattanasakun N, Ruangpanit Y, Rattanatabtimtong S, Attamangkune S. Physical, chemical and biological properties of cassava pulp. Proceedings of the 47th Kasetsart University Annual Conference, 2009; 2009 Mar 17-20: Kasetsart University, Bangkok, Thailand: Kasetsart University; 2009. pp.117-24.

14. Kaewwongsa W, Traiyakun S, Yuangklang, C, Wachirapakorn C, Paengkoum P. Protein enrichment of cassava pulp fermentation by Saccharomyces cerevisiae. J Anim Vet Adv 2011;10:2434-40.

15. Chumpawadee S, Soychuta S. Nutrient enrichment of cassava starch industry by-product using rumen microorganism as inoculums source. Pak J Nutr 2009;8:1380-2.

16. Thongkratoke R, Khempaka S, Molee W. Protein enrichment of cassava pulp using microorganisms fermentation techniques for use as an alternative animal feedstuff. J Anim Vet Adv 2010;9:285962 .

17. Vorachinda R, Bunyatratchata W, Suriyagamon S, et al. Improvement of protein content in cassava pulp by fungi fermentation. The 3rd International Conference on Sustainable Animal Agriculture for Developing Countries (SAADC2011); 2011 Jul 26-29: Nakhon Ratchasima, Thailand; 2011.pp. 307-11.

18. Society of Utilization of Self Supplied Feeds. The Guidebook for Quality Evaluation of Forage, 3th ed. Tokyo, Japan: Japan Grassland Agriculture and Forage Seed Association (In Japanese); 2009.

19. AOAC. Official Methods of Analysis. 17th ed. Arlington, VA: Association of Official Analytical Chemists;2000.

20. Van Soest PJ, Robertson JB, Lewis BA. Methods for dietary fiber, neutral detergent fiber and non-starch polysaccharides in relation to animal nutrition. J Dairy Sci 1991;74:3583-97.

21. Cai Y. Methods for feed evaluation of forages: Silage Analyses. In Japan Society of Grassland Science, editor. Field and laboratory methods for grassland science. Tokyo, Japan; Japan Livestock Technology Association; 2004. p. 279-83.

22. Yang XL, Li JL, Yu Z, et al. Influence of moisture content on the silage quality of Lolium multiflorum. J Anim Vet Adv 2014;13:702-5.

23. Menke KH, Steingass H. Estimation of energetic feed value obtained 
from chemical analysis and in vitro gas production. Anim Res Dev 1988;28:7-55.

24. SAS Institute. User's Guide: Statistics. Cary, NC: SAS Institute Inc; 1996.

25. Steel RGD, Torrie JH. Principles and Procedure of Statistics: A biometrical approach. 2nd ed. New York, NY: McGraw-Hill Book Company; 1980.

26. Steckley JD, Grieve DG, Macleod GK, Moran Jr ET. Brewer's yeast slurry, I. Composition as affected by length of storage, temperature, and chemical treatment. J Dairy Sci 1979;62:941-6.

27. Adeyemi OA, Eruvbetine D, Oguntona T, Dipeolu MA, Agunbiade JA. Enhancing the nutritional value of whole cassava root meal by rumen filtrate fermentation. Arch Zootec 2007;56:261-4.

28. Lounglawan P, Khungaew M, Suksombat W. Silage production from cassava peel and cassava pulp as energy source in cattle diets. J AnimVet Adv 2011;10:1007-11.

29. Umana R, Staples CR, Bates CB, Wilcox CJ, Mahanna WC. Effects of a microbial inoculant and (or) sugarcane molasses on the fermentation, aerobic stability, and digestibility of bermudagrass ensiled at two moisture contents. J Anim Sci 1991;69:4588-601.

30. Nishino N, Harada H, Sakaguchi E. Evaluation of fermentation and aerobic stability of wet brewers grains ensiled alone or in combination with various feeds as a total mixed ration. J Sci Food Agric 2003;83: 557-63.

31. Wang F, Nishino N. Resistance to aerobic deterioration of total mixed ration silage: Effect of ration formulation, air infiltration and storage period on fermentation characteristics and aerobic stability. J Sci Food Agric 2008;88:133-40.

32. Dung DV, Shang W, Yao W. Effect of crude protein levels in concentrate and concentrate levels in diet on in vitro fermentation. AsianAustralas J Anim Sci 2014;27:797-805.

33. Nitipot P, Nishida K, Chaithiang R, Pattarajinda V, Sommart K [Internet]. Metabolizable energy evaluation of pangola grass hay, cassava chip, cassava pulp and brewery waste in Thai native cattle; 2009 [cited 2014 Nov 5]. Available from: http://lib248.kku.ac.th/ annaul- conference/work/pdf/ AG\%2052-12-p55-7.pdf

34. Suksombat W, Lounglawan P, Noosen P. Energy and protein evaluation of five feedstuffs used in diet in which cassava pulp as main energy source for lactating dairy cow. Suranaree J Sci Technol 2006; 14:99-107.

35. Cerrillo MA, Juarez RAS. In vitro gas production parameters in cacti and tree species commonly consumed by grazing goats in a semi arid region of North Mexico. Livest Res Rural Dev 2004;16:4-9.

36. Getachew G, Robinson PH, DePeters EJ, Taylor SJ. Relationships between chemical composition, dry matter degradation and in vitro gas production of several ruminant feeds. Anim Feed Sci Technol 2004;111:57-71.

37. Coblentz WK, Nellis SE, Hoffman PC, et al. Unique interrelationships between fiber composition, water-soluble carbohydrates, and in vitro gas production for fall-grown oat forages. J Dairy Sci 2013; 96:7195-209. 